\title{
Coffee Agroforestry Performance in Pulau Panggung Sub-district, Tanggamus, Lampung, Indonesia
}

\author{
Fitriani ${ }^{1)}$, Bustanul Arifin ${ }^{2)}$, Wan Abbas Zakaria ${ }^{2}$, Hanung Ismono ${ }^{2)}$, and Rudi Hilmanto ${ }^{3)}$ \\ ${ }^{1)}$ Department of Economics and Business, Agribusiness, Politeknik Negeri Lampung, Indonesia \\ ${ }^{2)}$ Department of Agribusiness, Agriculture Faculty, University of Lampung, Bandar Lampung, Indonesia \\ ${ }^{3}$ Department of Forestry, Agriculture Faculty, University of Lampung, Bandar Lampung, Indonesia \\ * Corresponding author: barifin@uwalumni.com; fitriani@polinela.ac.id \\ Received: 23 March 2018 / Accepted: 20 May 2018
}

\begin{abstract}
Global buyer's concern towards sustainability production become a necessity recently, including in global market of coffee. Enhancing the coffee productivity must be a concern with sustainability condition. Coffee agroforestry is well known as a great solution to improve land productivity. Environmental services from natural resources will be assertion and sustainable. The aims of this study were to examine the agroforestry practices and to analysis the primary determinant of coffee farmer income. A study took place in Pulau Panggung sub-district, Tanggamus. Respondents were chosen randomly in a number of 408 coffee farmers. Descriptive statistic was used to tabulate and compile the coffee agroforestry performance criteria. Multiple regressions were conducted to analysis the relationship between coffee farmer incomes with the main determinant factors. Based on the analysis revealed the coffee-based complex agroforestry was a type of coffee agroforestry system in Pulau Panggung sub-district. Coffee plant density was 1,719 trees.ha ${ }^{-1}$ plants with multi purpose tree species (MPTS) shade trees 182 trees.ha ${ }^{-1}$. The MPTS as shade trees density in coffee farming attaint to $10.5 \%$, and raised more than five types of shade plants. Based on the regression model analysis results that simultaneously independent variables land area, land tenure, MPTS, education level, and experience in coffee planting were influenced the coffee farmer income model. Increased performance of coffee agroforestry system has a positive relation with the farmer income. This finding is very strategic to support the fact that the sustainable production trough coffee agroforestry was well-practiced by society forest (hutan kemasyarakatan). Development of the coffee agroforestry system in promoting the environmental services linked with the upper Sekampung watersheds management is becoming a critical step in the future.
\end{abstract}

Keywordsz: Coffee, agroforestry, Sekampung watersheds, land tenure

\section{INTRODUCTION}

Food and Agriculture Organization has released policy to increase agricultural productivity. It must be achieved through sustainable intensification (FAO, 2014). Agriculture sustainability means that the activities work economically, ecologically and socially sustainable nature (UU No. 12 of 1992). Global buyer concern towards sustainability production become a necessity recently, including in the global market of coffee. Sustainability condition must be an important step in enhancing coffee productivity. Perception of farmers in sustainable agricultural practices is influenced by socio- 
economic characteristics and searching behavior for information (Tatlidil et al., 2009). Social actors strongly influence decisions and selection of sustainable agriculture practices (Bernard et al., 2014); (Eakin et al., 2014). Unsustainable production conditions lead to negative environmental externalities that impact on the decline in the quality of environmental services and welfare (Adimiharja, 2008; Calder et al., 2008; van Noordwijk et al., 2008).

Coffee production in Lampung is concentrated in Tanggamus and West Lampung region. The appearances of farmer coffee plantation dominantly combined with the others in multicropping system. Based on work of Verbist \& Pasya (2004) combination of various coffee planting systems, rice fields, and riparian strips in Lampung was adequate to substitute environmental services closed to forest function. It contributes as a provider of watershed functions for both communities and hydropower management, furthermore for income resources. The sustainability of upper Sekampung watershed is linked with the cultivation system held by the community. Coffee farmers have realized that coffee agroforestry gives them to benefit more than monoculture (Fitriani et al., 2018). The expansion of coffee farming in the Ethiopian rainforest provided important benefits in the diversity of plant species conservation and carbon storage timber. Coffee agroforestry had the highest diversity of native trees of the productive system (Häger et al., 2014).

Coffee farming practices need more concern toward the aspect of conservation as a vital precondition of the key sustainability in the future. Coffee farms need shade trees. The kind of shade trees is a key factor in determining the sustainability of coffee farming. Planting shade trees is the main measurement for soil conservation in coffee agro-ecosystems (Evizal et al., 2012). Coffee agroforestry system is well known as multistrata/complex and simple agroforestry (Suprayogo et al., 2010; Hairiah, 2010). The canopy multi-strata system has two functions i.e. the function of the land and the financial function by providing income for farmers in a sustainable manner (Sanudin et al., 2016). Then, coffee agroforestry is one important adaptive sustainable production in upper watersheds.

Awareness of agroforestry practice varied at coffee farmer level. Coffee agroforestry practiced need investment allocation which depend on farmer resources. It also related to the property right on land tenure. The jurisdiction of land property right will impact on farmer decision in allocating the resources to apply the agroforestry system in coffee farming.

One of the critical factors for the successful practice of coffee agroforestry is highly dependent on the rights of the land (property right). Adoption decisions of coffee agroforestry mainly is determined by land tenure, land slope, and soil quality (Arifin et al., 2014; Soliha, 2012). Land tenure represented the right of ownership of land resources. It has implications for the utilization and maintenance of its sustainability. Limitations of clarity and certainty of land tenure are the main factors in driving deforestation in many countries. Only when land tenure is legally guaranteed and at the practical level, longterm investment in a sustainable management framework can be realized (Eliasch, 2008). The validity of ownership of goods or services is very important. Without property rights, investment incentives for sustainability will often be absent, because they are only free riders (Fisher et al., 2008).

However, the fact that property rights are not the same among economic actors. Proper property right is a resource for a strong commitment to productivity improvement. Only with clear rules of the game between agencies, resource actors and users in mutual 
trust and collaboration, transaction costs and externalities can be minimized and managed efficiently to achieve optimal Pareto objectives for each element involved in the system (Hanley \& Barbier, 2009). This difference in management rights resulted in the uncertainty of jurisdiction in business, including investment in the implementation of sustainable coffee production.

The main activities of coffee farmers conducted is to gain adequate income then to fulfil their needs. Coffee farmer decision in optimizing the income depends on many important factors, internally and externally. Internal situation is the variables linked with personal characteristic of a farmer, including the background of education, experience, age, and family member and others. Coffee agroforestry practiced was a part of the external situation, which could affect farmer income. The number of shade trees, the access to land tenure, and land area were included as the main determinant of coffee farmer income.

Therefore, the purpose of this study was to investigate the coffee agroforestry practices in Pulau Panggung sub-district, Tanggamus, including analyzing the primary determinant of coffee farmer income.

\section{MATERIALS AND METHODS}

This Study took place in Pulau Panggung sub-district, Tanggamus. Pulau Panggung sub-district, Tanggamus has territory attaint to 28.544,90 ha. Pulau Panggung consists of 21 villages. Four village is purposively chosen i.e. Pulau Panggung, Tekad, Batu Bedil, and Tanjung Rejo villages. The main consideration was the coffee farming establishment in those areas. Coffee farmer sampling was designed by simple random sampling, total 408 coffee farmers. Figure 1 described the site location.

Agroforestry is a land management system that the system comprises a long list of sustain- able land management practices, including crop diversification, long rotation system for soil conservation, yards, border planting, annual crops, intercropping hedges, living fences, or mixed crops with forestry strata as well as integration of crops and livestock (Combe, 1982; Mbow et al., 2014; Jamnadass et al., 2013). Agroforestry practices in coffee farming represented by shade trees planting called multipurpose tree species (MPTS). Coffee agroforestry is the coffee plantation system plant with adequate multi shade trees as MPTS. Coffee agroforestry is categorized as simple agroforestry and complex agroforestry or multi strata shade trees. When the kind of shade trees more than five types it represent as complex coffee agroforestry (Suprayogo et al., 2010). Complex coffee agroforestry is also knnown as coffee with MPTS (multipurpose trees species). MPT has high-canopy shade trees. Based on work of Arifin et al. (2014) MPT categorized as MPT is based on wood and non-wood. MPT is based on wood timber species as shade tree. MPTs non-wood are various annual fruit tree species plant, such as durian (Durio zibethinus), petai (Parkia speciosa), jengkol (Archidendron pauciflorum), candlenut (Aleurites moluccana) avocado (Persea americana), and jackfruit (Artocarpus heterophyllus). Number of trees planted with coffee trees is used to determine the coffee agroforestry performance in the site location.

In practice, there are currently three conditions of land tenure in the centre of coffee production, i.e. farmers holding community based agro-forestry (Izin Usaha Hutan Kemasyarakatan/IUHKm), private, and non$\mathrm{HKm}$. Private holds land certificates. Non$\mathrm{HKm}$ means they are not including in both categories mentioned before. It could represented of farmers who have long managed land, but has no certificate of ownership (clan) and also the farmers who are still processing 


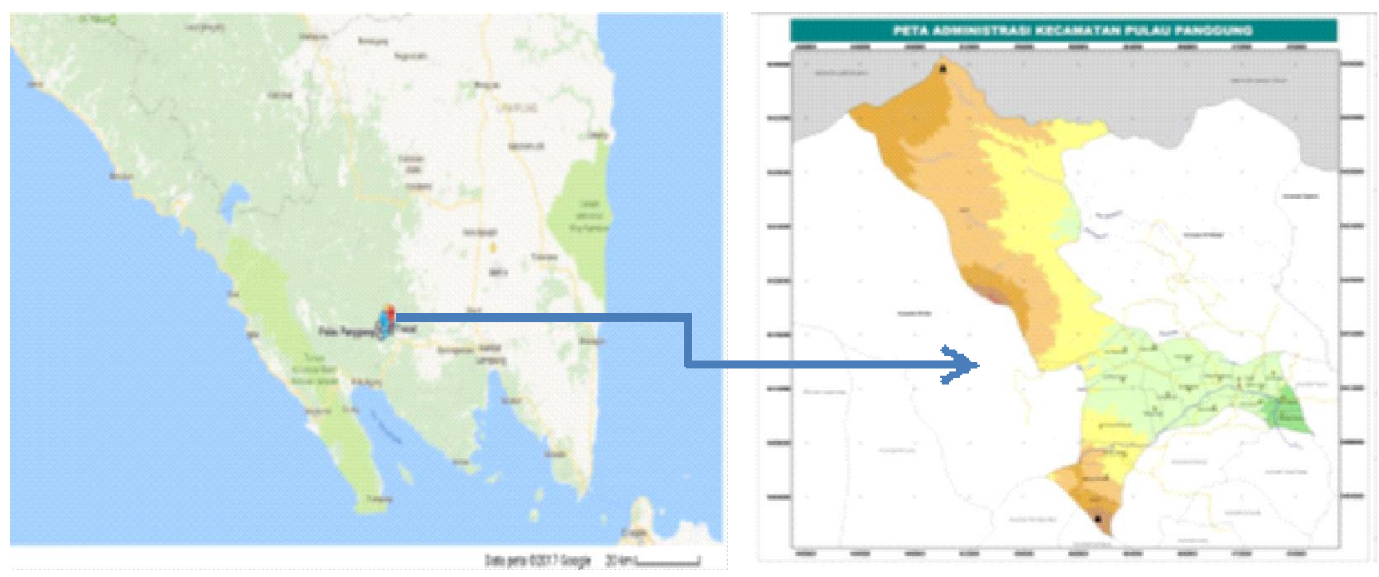

Figure 1. Site location

the partnership system set by Forest Management Office (Arifin et al., 2014).

Statistic descriptive was used to tabulate and compile the coffee agroforestry performance criteria. The relationship between coffee farmer incomes with the main factors that influenced was conducted by multiple regressions. Coffee farmer income set as a dependent variable $(Y)$. Land tenure $\left(\mathrm{X}_{1}\right)$ and the number of shade trees (MPTS) was represent of coffee agroforestry $\left(\mathrm{X}_{2}\right)$, level of education $\left(\mathrm{X}_{3}\right)$, and experiences in coffee production $\left(\mathrm{X}_{4}\right)$ were as dependent variables. The formulation of the income model, noted as equation bellows:

$$
\begin{array}{ll}
Y= & \beta 0+\beta 1 X 1+\beta 2 X 2+\beta 3 X 3+\beta 4 X 4+\beta 5 X 5+ \\
& e \ldots \ldots .(1) \\
\mathrm{Y} & =\text { Income (IDR/year) } \\
\mathrm{X}_{1} & =\text { Land area (ha) } \\
\mathrm{X}_{2} & =\text { Land tenure }(1=\mathrm{HKm} ; 2=\text { Non_HKm) } \\
\mathrm{X}_{3} & =\text { Shade trees (amount of trees) } \\
\mathrm{X}_{4} & =\text { Education (year) } \\
\mathrm{X}_{5} & =\text { Experience (year) }
\end{array}
$$

\section{RESULT AND DISCUSSION}

\section{Coffee Agroforestry}

Pulau Panggung sub-district land use is mostly as plantation area (56.1\%) and dry land farming $(24.1 \%)$. The population is around 10.609 households. Land for coffee plantation reaches 9.675 ha, coconut (646 ha), pepper (189 ha), and cocoa (124 ha) (Tanggamus Statistics Office). The coffee planting age was 51 percent between the ages of 5 and 19 years (Incamilla et al., 2015). The rest was more than 20 years old trees. Respondent background educations were elementary school (46.6\%), junior high school (24.8\%), and senior high school (22.3\%). They experienced in coffee cultivation in average attaint to 18.5 years. The farmer age on average was 44 years old. Most of them cultivate coffee as the main source for household income.

Based on the statistic descriptive displayed at Table 1 performed that shade trees plant categorized as MPTS non wood and wood based. MPTS based on wood represented by 8 kinds of tress, while MPTS based on non-wood trees 5 type of trees. MPTS wood is: dadap (Erythrina sububrams), medang (Phoebe sp), cempaka (M. champaca), albasia (Albazia sp), sengon (Paraserianthes sp), jati (Tectona grandis), and lamtoro (Leucaena $\mathrm{sp)}$ (Figure 3). While pete (Parkia speciosa), durian (Durio zibethinus), clove (Syzygium aromaticum), jengkol (Archidendron pauciflorum) as non-wood MPTS (Figure 4). Multi cropping plants also appear such 
as pepper, cocoa, banana, and rubber. Descriptive statistic of shade trees in coffee farming was shown in Table 1. While boxplots of land area and coffee trees were sets in Figure 2.
MPTS trees density were dominantly by dadap (Erythrina sububrams) (37 trees.ha' ${ }^{-1}$, albasia (Albazia sp) (86 trees.ha- $\left.{ }^{-1}\right)$, sengon (Paraserianthes sp) (12 trees.ha $\left.{ }^{-1}\right)$, and jengkol (Archidendron pauciflorum) (10 trees.ha-1 ${ }^{-1}$.

Table1. Descriptive statistic coffee agroforestry performance

\begin{tabular}{|c|c|c|c|c|c|c|c|}
\hline Variable & $\mathrm{N}$ & Mean & SE Mean & StDev & Mini & Median & Maximum \\
\hline \multicolumn{8}{|c|}{$\begin{array}{l}\text { MPTS (multi purpose tree species) } \\
\text { wood }\end{array}$} \\
\hline Erythrina variegata (Dadap) & 408 & 49.10 & 7.67 & 154.88 & 0.00 & 0.00 & 1500.00 \\
\hline Phoebe sp (Medang) & 408 & 0.949 & 0.360 & 7.275 & 0.000 & 0.000 & 100.000 \\
\hline M. champara (Cempaka) & 407 & 13.17 & 2.81 & 56.74 & 0.00 & 0.00 & 1000.00 \\
\hline Albizia chinensis (Sengon) & 408 & 129.1 & 12.6 & 255.4 & 0.0 & 20.0 & 2000.0 \\
\hline Tectona grandis (Jati) & 408 & 2.125 & 0.436 & 8.798 & 0.000 & 0.000 & 100.000 \\
\hline Leucaena leucocephala (Lamtoro) & 408 & 7.74 & 2.36 & 47.69 & 0.00 & 0.00 & 500.00 \\
\hline \multicolumn{8}{|l|}{$\begin{array}{l}\text { MPTS (multi purpose tree species) } \\
\text { non-wood }\end{array}$} \\
\hline Parkia speciosa (Pete) & 408 & 3.118 & 0.371 & 7.496 & 0.000 & 1.000 & 100.000 \\
\hline D. zibethinus (Durian) & 408 & 1.218 & 0.211 & 4.267 & 0.000 & 0.000 & 60.000 \\
\hline Persea americana (Avocado) & 408 & 0.3725 & 0.0586 & 1.1828 & 0.0000 & 0.0000 & 10.0000 \\
\hline Syzygium aromaticum (Clove) & 408 & 3.328 & 0.992 & 20.029 & 0.000 & 0.000 & 250.000 \\
\hline Archidendron sp (Jengkol) & 408 & 13.54 & 1.29 & 25.96 & 0.00 & 6.00 & 300.00 \\
\hline Coffee trees & 408 & 2306.9 & 85.2 & 1720.2 & 20.0 & 2000.0 & 12000.0 \\
\hline Land area (ha) & 408 & 1.3419 & 0.0444 & 0.8973 & 0.2500 & 1.0000 & 6.0000 \\
\hline
\end{tabular}

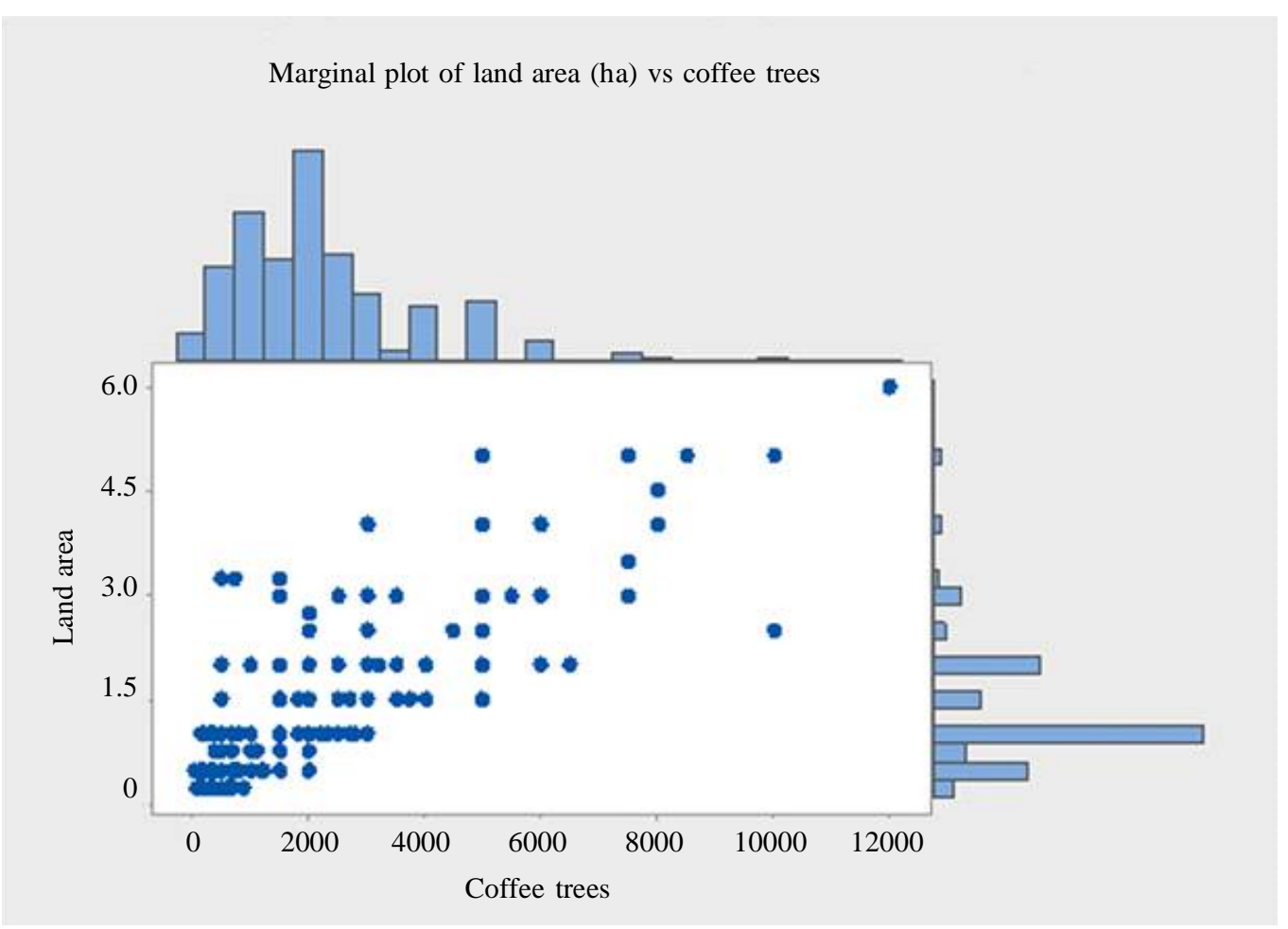

Figure 2. Marginal plot of land area with coffee trees 


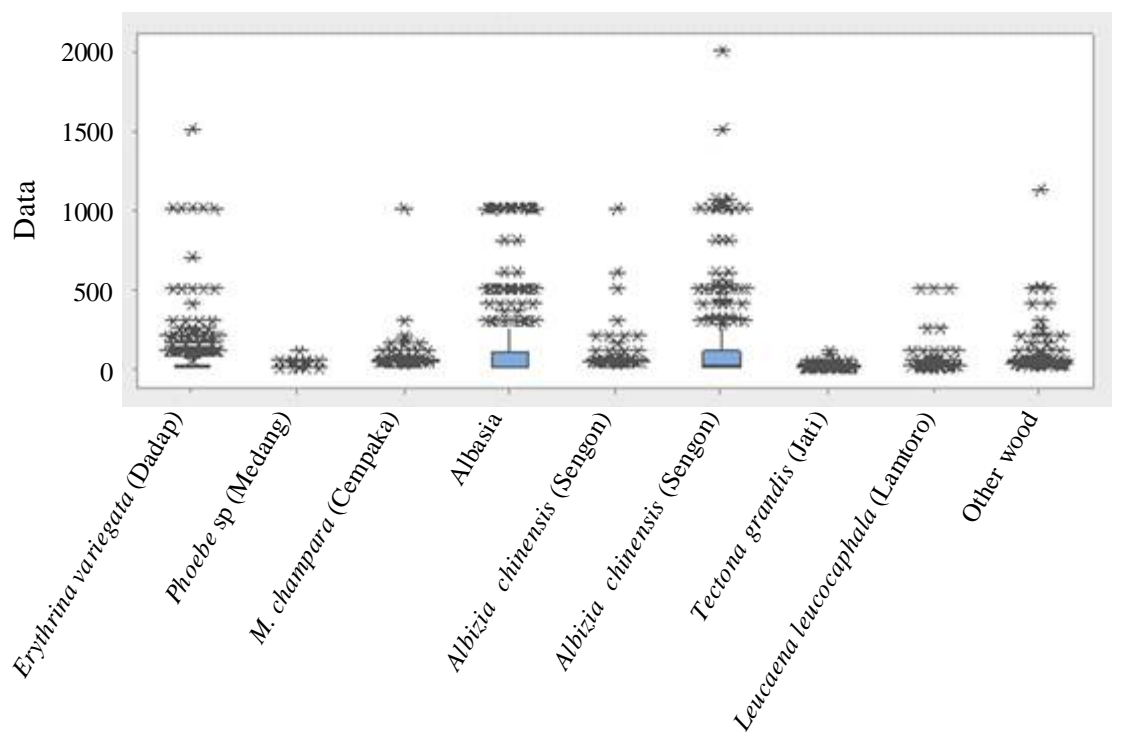

Figure 3. Box plots of MPTS (multi purpose tree species) wood trees

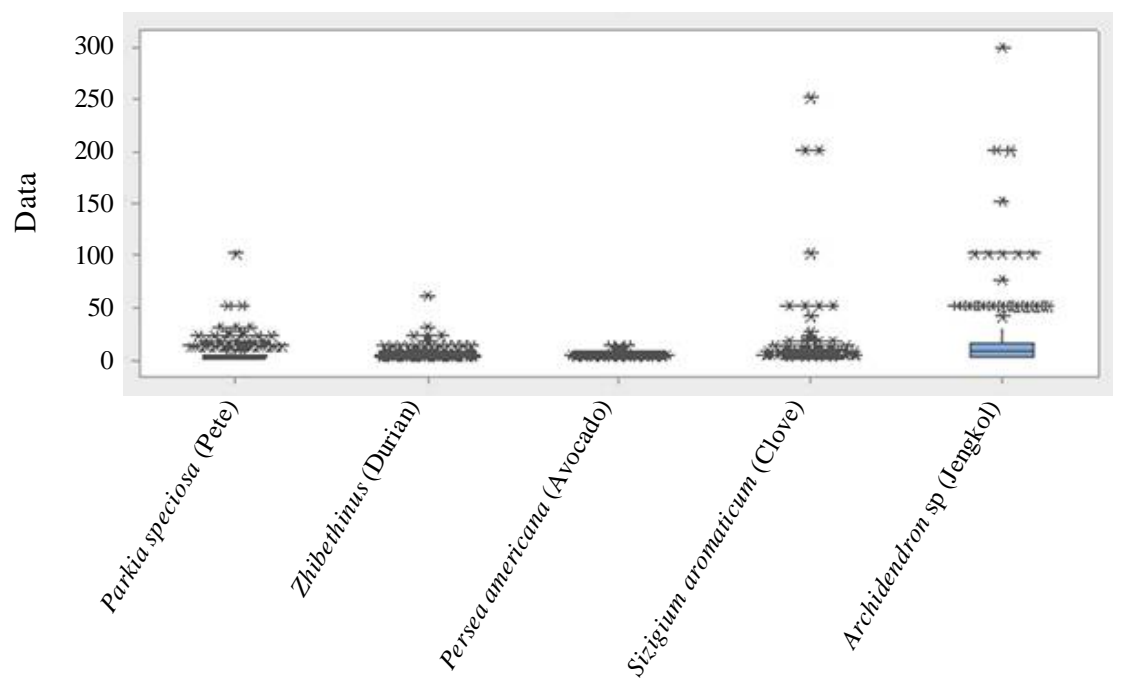

Figure 4. Box plots of MPTS (Multi Purpose Tree Species) non-wood trees

MPTS density in average was 187 trees.ha $^{-1}$ ). Based on Table 3 was revealed that "mean" of coffee plant density amount to 1,719 coffee trees.ha ${ }^{-1}$ while growth with shade trees (MPTS) attain to 182 trees.ha $^{-1}$. The "median" of coffee plant density was attaint to 1,490 coffee trees.ha ${ }^{-1}$ while growth with shade trees (MPTS) attain to 89 trees.ha $^{-1}$. The MPTS as shade trees density in coffee farming attaint to $10.5 \%$
This condition revealed as the important fact that coffee agroforestry in Pulau Panggung classified as coffee-based complex agroforestry. The coffee-based complex agroforestry showed coffee plant grown using more than five types of shade plants. The basal area of coffee plantations on agroforestry systems is less than $80 \%$ (Suprayogo et al., 2010). Coffeebased agroforestry systems are an important requirement for increasing land productivity. 
Coffee plants need shade trees, biologically, so the coffee is generally grown in a mixed system (agroforestry) ranging from simple system to complex mixture (multistory) that resembles a forest. In simple agroforestry systems, common shade tree planted is a legume such as dadap (Erythrina sububrams), Gliricidia (Gliricidia sepium) and leucaena (Leucaena glauca). Farmers plant trees to shade coffee as well as fruit trees, timber (MPTS) on the grounds of economic benefits and conservation of soil and water (Hairiah, 1995). This is also related to coffee multi story type called "protective garden" that can provide environmental services and simultaneously improve the welfare of farmers. The protected garden is tree-based systems managed by farmers who provide environmental services similar to the forest. Coffee multistory provides environmental services through water and soil conservation which is better than coffee without shade or just a simple shade system. Multistory also maintain soil nutrients, reduce and minimize the risk of landslides and improve soil fertility by increasing the amount of nitrogen in the soil (Suyamto \& Noordwijk, 2004).
The implementation of coffee agroforestry system could guarantee the sustainability of economic, social and environmental in longterm. Coffee agroforestry systems (CAFS) showed the structural and biological diversity of agroforest species complex and rich. CAFS reveal the degree of heterogeneity comparatively superior to monoculture crops. CAFS has been regarded as complex production systems and sustainable resilient according to conservation (Pinard et al., 2014). The implementation of coffee agro forestry system could guarantee the sustainability of economic, social and environmental in long-term. This also support by previous research that agroforestry system in coffee is able to maintain environmental conditions (Yuliasmara, 2017). Organic farming has higher levels of shade trees and more strata than conventional farming (Börner et al., 2007).

\section{Farmer Income Determinant}

Land tenure is very important for the certainty in farming. Land tenure for coffee farming in Pulau Panggung sub-district dominantly was by $\mathrm{HKm}$ permit (93.6\%) (Table 2).

Table 2. Land tenure on coffee farming

\begin{tabular}{lccc}
\hline & Code & Frequency & Percent \\
\hline Society forest $(\mathrm{HKm})$ & 1 & 382 & 93.63 \\
Non HKm & 2 & 25 & 6.13 \\
\hline
\end{tabular}

Table 3. Statistic descriptive of area, MPTS and coffee

\begin{tabular}{|c|c|c|c|}
\hline Land & Area (ha) & MPTS (trees) & Coffee (trees) \\
\hline Mean & 1.34 & 244 & 2306 \\
\hline Standard error & 0.04 & 18 & 85 \\
\hline Median & 1.00 & 120 & 2000 \\
\hline Mode & 1.00 & 15 & 2000 \\
\hline Standard deviation & 0.90 & 356 & 1722 \\
\hline Sample variance & 0.81 & 126683 & 2966203 \\
\hline Kurtosis & 4.66 & 18 & 5 \\
\hline Skewness & 1.89 & 4 & 2 \\
\hline Range & 5.75 & 3267 & 11980 \\
\hline Minimum & 0.25 & 0 & 20 \\
\hline Maximum & 6.00 & 3267 & 12000 \\
\hline Sum & 547.50 & 99698 & 938720 \\
\hline Count & 408.00 & 408 & 407 \\
\hline Largest (1) & 6.00 & 3267 & 12000 \\
\hline Smallest (1) & 0.25 & 0 & 20 \\
\hline
\end{tabular}


The history of HKm in Lampung started by Forestry Ministry Decree No.622/Kpts-II/ 1995. The development of HKm recognition was still very slow in 1997, so the Minister of Forestry issued Decree No. 677/KptsII/1997, amending the Decree No. 622/KptsII/1995 which provides a space for the granting of forest utilization rights to a community known as Community Forestry Rights (HPHKm) limited to non-timber forest utilization. In 2001, the Ministry of Forestry issued Decree No. 31/Kpts-II/2001, which gives members the freedom to the community as the main actors in forest management. The next policy improvement is the issuance of Forestry Minister's Regulation No. P.37/Menhut-II/ 2007 on Community Forests and subsequently followed by changes (Permenhut No.P.18/Menhut-II/2009, Permenhut No. P.13/Menhut-II/2010, to Permenhut No. P52/Menhut-II/2011). The regulation explains the technical guidance of the procedure of obtaining HKm's rights. HKm is a state forest used to empower local people. HKm is only applied in protected forest area and production forest. The provision is that its forests are not burdened with rights or permits in the use of forest products and become the source of local livelihoods. The IUPHKm permit is granted for 35 years and extended according to the evaluation result every 5 years. Tanggamus region has $32 \mathrm{HKm}$ group members. HKm in Lampung Province is already underway nearly 18 years with all the dynamics in its implementation.

The land area of coffee agroforestry on average was 1.3 ha, the minimum 0.25 ha, the maximum attaint to 6 ha. The statistic descriptive of the variables in the income model displayed in Table 4. Based on the equation model (1), the regression analysis performed that the model represented the coffee farmer income in the goodness of fit criteria. Regression income model in fit performed with $\mathrm{F}_{\text {value }}$
58.13 Sig $1.89 \mathrm{E}-45$ and the $\mathrm{R}^{2}$ value reached $64 \%$ (Table 5).

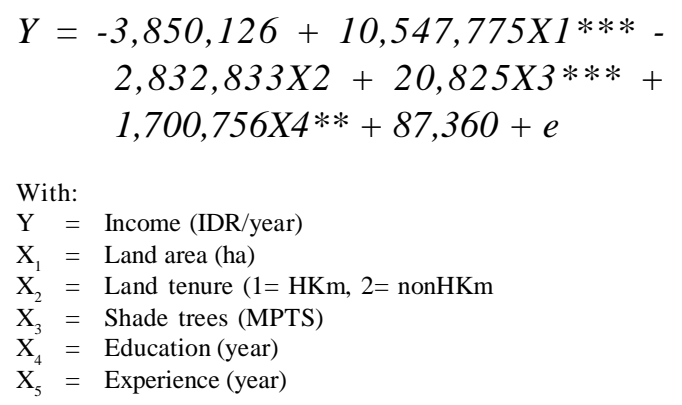

Simultaneously the all independent variables affected the dependent variable. Partially, land area, shade trees (MPTS), and education level significantly influenced the income. All the sign of coefficient was properly with the theory. Land area, MPTS, education level, and experience have a positive relation with the income. The sign of land tenure variable was negative. In this case, the negative sign and the coefficient have represented the slope of differences between $\mathrm{HKm}$ and no-HKm land tenure. Land tenure is very important for the certainty in farming. The negative sign of land ownership means that without the certainty in land ownership the farmers were threatened by failure risk. This also revealed as fact that the jurisdiction of land tenure was very important in determining the income. Based on the regression analysis, the equation of the factors influenced the coffee farmer income.

The results performed that coffee agroforestry system gave positive impact by income. MPTS represented of agroforestry has a positive effect on income. The impact evaluation shows that both agroforestry systems and coffee certificates in Sekampung watersheds Tanggamus have positive significant impacts on improving economic benefits (Incamilla et al., 2015). Coffee agroforestry systems have positive significant impacts on improving environmental benefits (Arifin et al., 2014). Based on the work of Wibawa et al. (2010) that the kind of shade trees 
Table4. Descriptive statistic of variable

\begin{tabular}{lrrrrrr}
\hline Criteria & $X_{1}$ & $X_{2}$ & $X_{3}$ & $X_{4}$ & $X_{5}$ & $Y$ \\
\hline Mean & 1.34 & 1 & 244 & 3 & 19 & $18,784,810$ \\
St Error & 0.04 & 0 & 18 & 0 & 1 & $1,088,258$ \\
Median & 1 & 1 & 120 & 3 & 18 & $12,490,000$ \\
Kurtosis & 4.66 & 11 & 18 & 1 & 0 & 22.01 \\
Skewness & 1.89 & 3 & 4 & 1 & 1 & 3.93 \\
Range & 5.75 & 2 & 3267 & 6 & 64 & $208,705,000$ \\
Minimum & 0.25 & 0 & 0 & 0 & 62,000 \\
Maximum & 6 & 2 & 3267 & 6 & 65 & $208,728,000$ \\
\hline
\end{tabular}

$\mathrm{Y}=$ Income (IDR/year) $\mathrm{X}_{1}=$ land area (ha) $\mathrm{X}_{2}=$ Land tenure $\mathrm{X}_{3}=$ Shade trees $\mathrm{X}_{4}=$ Education (year) $\mathrm{X}_{5}=$ Experience (year)

Table5. Regression output of the model of coffee farmer's income

\begin{tabular}{|c|c|c|c|c|c|}
\hline \multicolumn{2}{|l|}{$\begin{array}{l}\text { SUMMARY } \\
\text { OUTPUT }\end{array}$} & & & & \\
\hline \multicolumn{2}{|c|}{ Regression Statistics } & & & & \\
\hline Multiple R & 0.647802834 & & & & \\
\hline R Square & 0.419648512 & & & & \\
\hline Adjusted R Square & 0.41243021 & & & & \\
\hline Standard Error & 1684968 & & & & \\
\hline Observations & 408 & & & & \\
\hline \multicolumn{6}{|l|}{ ANOVA } \\
\hline & $d f$ & $S S$ & $M S$ & $F$ & Significance $F$ \\
\hline Regression & 5 & $8.2510^{+16}$ & $1.6510^{+16}$ & 58.13673 & $1.887510^{-45}$ \\
\hline Residual & 402 & $1.1410^{+17}$ & $2.8410^{+14}$ & & \\
\hline \multirow[t]{2}{*}{ Total } & 407 & $1.9710^{+17}$ & & & \\
\hline & Coefficients & Standard error & t Stat & P-value & \\
\hline Intercept & -3850126 & 5226977 & -0.73659 & 0.461803 & \\
\hline $\mathrm{X} 1$ & 10547775 & 1014692 & 10.39505 & $1.4110^{-22} * * *$ & \\
\hline $\mathrm{X} 2$ & -2832833 & 3429505 & -0.82602 & 0.409284 & \\
\hline $\mathrm{X} 3$ & 20825.37632 & 2507.723 & 8.304495 & $1.5510^{-15} * * *$ & \\
\hline $\mathrm{X} 4$ & 1700756 & 879837 & 1.933037 & $0.053934 * *$ & \\
\hline $\mathrm{X} 5$ & 87360 & 77091 & 1.133212 & 0.257801 & \\
\hline
\end{tabular}

in coffee farming influenced the amount of carbon stock. Just such as agroforestry practices in China and elsewhere that provide long-term benefits for the improvement of the economy of the people (Hildreth, 2008).

\section{CONCLUSION}

The coffee agroforestry system in Pulau Panggung sub-district was shown as coffeebased complex agroforestry. Coffee plant density was 1,719 trees.ha $^{-1}$, grown with shade trees (MPTS) 182 trees.ha $^{-1}$. The MPTS as shade trees density in coffee farming attaint to $10.5 \%$, and rise more than five types of shade plants. Coffee-based agroforestry systems are as a path in increasing land productivity. The coffee farmer income model was determined by land area, land tenure, MPTS, education level, and experience in coffee planting simultaneously. MPTS represented agroforestry had a positive effect on income. Enhancement the performance of coffee agroforestry system had a positive relation with the farmer income. This finding is very strategic to support the fact that the sustainable production through coffee agroforestry was well-practiced by HKm. Development of the coffee agroforestry system in promoting environmental services linked with the upper Sekampung watersheds management is becoming a critical step in the future. 


\section{ACKNOWLEDGMENT}

This work was supported in part by the Grant Research Collaboration between Lampung University (UNILA-Agricultural Economics Indonesia), Shiga University (Research Centre for Sustainability and Environment, Japan) and Research Institute for Human Nature (RIHN), Japan. (Special thanks to Ryohei Kada and Katsuya Tanaka).

\section{REFERENCES}

Adimiharja, A. (2008). Teknologi dan strategi konservasi tanah dalam kerangka revitalisasi pertanian. Pengembangan Inovasi Pertanian, 1, 105-124.

Arifin, B.; K. Tanaka; R. Kada \& H. Ismono (2014). The roles of agroforestry system and coffee certificate in improving farmers economic and Environmental Benefits in Sumatra, Indonesia. In: Internatonal Symposium on Mitigating Environmental Risks in Indonesian Watersheds through Payment for Environmental Services. Lampung University. Lampung.

Bernard, F.; M. van Noordwijk; E. Luedeling; G.B. Villamor; G.W. Sileshi \& S. Namirembe (2014). Social actors and unsustainability of agriculture. Current Opinion in Environmental Sustainability, 6, 155-161.

Börner, J.; A. Mendoza \& S.A. Vosti (2007). Ecosystem services, agriculture, and rural poverty in the Eastern Brazilian Amazon/ : Interrelationships and policy prescriptions. Ecological Economic, 64, 356-373.

Calder, I.; Æ.A.Gosain; M.S.R. Mohan; R.Æ. Charles; J. Garratt \& E. Bishop (2008). Watershed development in India. 2. New approaches for managing externalities and meeting sustainability requirements, Environment, Development and Sustainablility, 10, 427-440.

Combe, J. (1982). Agroforestry techniques in tropical countries: Potential and limitations. Agroforestry System, 7, 13-27.
Eakin, H.; C.M. Tucker; E. Castellanos; R.D. Juan \& F.B. Helda (2014). Adaptation in a multi-stressor environment perceptions and responses to climatic and economic risks by coffee growers in Mesoamerica, Environment, Development and Sustainablility, 16, 123-139.

Eliasch, J. (2008). Climate Change: Financing Global Forests. Earthscan Publishing for Sustainable Future. London.

Evizal, R.; I.D. Prijambada; J. Widada \& D. Widianto (2012). Soil bacterial diversity and productivity of coffee shade tree. Journal of Tropical Soils, 17, 181-187.

FAO (2014). Evidence-Based Assessment of The Sustainability and Replicability of Itegrated Food-Energy System. Food and Agriculture Organization of the United Nation. Rome, Italy.

Fisher, B.; K. Turner; M. Zylastra; R. Brouwer; R. de Groot; S. Faber; P. Ferraro; R. Green; D. Hadley; J. Harlow; P. Jefferiss; C. Kirkby; D. Morling; S. Mowatt; R. Naidooo; J. Paavola; B. Strassburg; D. You \& A. Balmford (2008). Ecosystem services and economic theory: Integration for policy-relevan research. Ecological Applications, 18, 2050-2067.

Fitriani; B. Arifin; W.A. Zakaria \& R.H. Ismono (2018). Coffee agroforestry for sustainability of Upper Sekampung Watershed management. pp. 1-13. In: $2^{\text {nd }}$ International Conference on Biomass: Toward Sustainable Biomass Utilization for Industrial and Energy Applications. IOP Conference Series: Earth and Environmental Science.

Häger, A.; M. Fernández; M. Faye; R. Acuña \& A. Contreras (2014). Agriculture, ecosystems and environment effects of management and landscape composition on the diversity and structure of tree species assemblages in coffee agroforests. Agriculture, Ecosystems and Environment, 199, 43-51.

Hairiah, K.; M.A. Sardjono \& S. Sabarnurdin (1995). Pengantar Agroforestri. ICRAF, Bogor, Indonesia. 
Hairiah, K. \& S. Ashari (2013). Pertanian masa depan: Agroforestri, manfaat, dan layanan lingkungan. pp. 23-35. In: Prosiding Seminar Nasional Agroforestri. Agroforestri untuk Pangan dan Lingkungan yang Lebih Baik. Malang, 21 Mei 2013. Faperta UB, Litbang Kehutanan, ICRAF, MAFI.

Hanley, N. \& E.B. Barbier (2009). Pricing Nature Cost Benefit Analysisi and Environmental Policy. Edwar Elgar Publishing Inc. Northampton.

Hildreth, L.A. (2008). The economic impacts of agroforestry in the Northern Plains of China. Agroforest System, 72, 119-126.

Incamilla, A.; B. Arifin \& A. Nugraha (2015). Sustainability of coffee agroforestry farming in Pulau Panggung sub-district of Tanggamus Regency. Jurnal IlmuIlmu Agribisnis, 3, 260-267.

Jamnadass, R.; F. Place; E. Torquebiau; M. Iiyama; G.W. Sileshi; K. Kehlenbeck; E. Marters; S. Macmullin; J.C. Weber \& I.K. Dawson (2013). Agroforestry for food and nutritional security. Unasylva, 64, 23-29.

Mbow, C.; P. Smith; D. Skole; L. Duguma \& M. Bustamante (2014). Achieving mitigation and adaptation to climate change through sustainable agroforestry practices in Africa. Current Opinion in Environmental Sustainability, 6, 8-14.

Pinard, F.; E. Joetzjer; K. Kehlenbeck \& R. Kindt (2014). Are coffee agroforestry systems suitable for circa situm conservation of indigenous trees? A case study from Central Kenya. Biodiversity Conservation, 23, 467-495.

Sanudin; S.A. Awang; R. Sadono \& R.H. Purwanto (2016). Perkembangan hutan kemasyarakatan di Propinsi Lampung. Jurnal Manusia dan Lingkungan, 23, 276-283.

Soliha, I. (2012). Keberlanjutan Usahatani Kopi Rakyat Robusta ( Robusta L.) dengan Nanugan dan Tanpa Naungan di Desa
Kemiri Kecamatan Panti. Thesis, Fakultas Pertanian, Universitas Jember, Jember.

Suprayogo, D.; K. Hairiah; M. Van Noordwijk \& G. Cadisch (2010). Agroforestry interactions in rainfed agriculture: Can hedgerow intercropping systems sustain crop yield on an ultisol in Lampung (Indonesia)? Agrivita, 32, 205-216.

Suyamto, D.A. \& M. Van. Noordwijk (2004). Respon petani kopi terhadap gejolak pasar dan konsekuensinya terhadap fungsi tata air: Suatu pendekatan pemodelan. Agrivita, 26, 14-17.

Tatlidil, F.F.; I. Boz \& H. Tatlidil (2009). Farmers perception of sustainable agriculture and its determinants: A case study in Kahramanmaras province of Turkey. Environment, Development and Sustainability, 11, 1091-1106.

van Noordwijk, M.; D.A.Suyamto; B. Lusiana; A. Ekadinata \& K. Hairiah (2008). Facilitating agroforestation of landscapes for sustainable benefits: Tradeoffs between carbon stocks and local development benefits in Indonesia according to the FALLOW model. Agriculture, Ecosystems and Environment, 126 (1-2), 98-112.

Verbist, Bruno; Pasya, G. (2004). Perspektif sejarah status kawasan hutan, konflik dan negosiasi di Sumberjaya, Lampung Barat-Propinsi Lampung. Agrivita, 26, 20-28.

Wibawa, A.; F. Yuliasmara \& R. Erwiyono (2010). Estimasi cadangan karbon pada perkebunan kopi di Jawa Timur, Pelita Perkebunan, 26, 1-11.

Yuliasmara, F. (2017). El Nino effect on coffee growth and productivity on several agroforestry systems in Gumitir Mountain Coffee Farms, East Java, Indonesia. Pelita Perkebunan, 33, 168-179.

$* * 0 * *$ 